\title{
Effect of hypophysectomy on mouse oocyte maturation in vitro
}

\author{
Dianne Moore Smith and D. Y. Tenney \\ Laboratory of Human Reproduction and Reproductive Biology and Department of Physiology, \\ Harvard Medical School, Boston, Massachusetts 02115, U.S.A.
}

\begin{abstract}
Summary. There was no difference in frequency of maturation of oocytes obtained from mice hypophysectomized for 2 weeks compared to those from sham-operated or untreated (control) animals of the same age. By 7 weeks, and also at 12 and 17 weeks, the incidence of polar body formation in vitro was significantly reduced. The number of oocytes which remained meiotically inactive in culture was increased at 7 , 12 and 17 weeks after hypophysectomy. This decrease in spontaneous oocyte maturation in vitro could be partly overcome by administering exogenous PMSG, oestradiol-17 $\beta$ or PMSG + oestradiol-17 $\beta$, but not progesterone or $\mathrm{hCG}$, to hypophysectomized mice.
\end{abstract}

\section{Introduction}

The capacity of mammalian oocytes for spontaneous maturation in vitro is positively correlated with the degree of oocyte growth in hamsters (Iwamatsu \& Yanagimachi, 1975), mice (Sorensen \& Wassarman, 1976) and man (K. P. McNatty \& D. M. Smith, unpublished results). We are interested in determining whether there are factors, e.g. the endocrine status of an animal, which can affect the potential of mammalian oocytes to resume meiosis after they have become fully grown in the pre- or early-antral follicle. It has been reported that the oocytes of pigs (Hunter, Cook \& Baker, 1976) and rhesus monkeys (Smith, Conaway \& Kerber, 1978) show the greatest incidence of maturation when obtained from animals with high levels of circulating oestrogens. If high rates of maturation can be correlated with sex steroid secretion, then ovaries less active in steroid secretion, e.g. as a result of hypophysectomy, might be expected to yield oocytes with a decreased capacity for maturation. We have tested this hypothesis in hypophysectomized mice.

\section{Materials and Methods}

\section{Animals}

Swiss albino (CD-1) mice, 21-23 days of age, were obtained from Charles River Breeding Laboratories, Inc. (Wilmington, Massachusetts). For each experiment, a shipment of 40 or more mice was randomly distributed into 3 groups: control (no treatment), those for hypophysectomy and those to be sham-operated. Hypophysectomy was carried out with tribromoethanol (Avertin) anaesthesia on Days 23-27 after birth and before vaginal opening. The parapharyngeal approach described by Zarrow, Yochim \& McCarthy (1964) for rats was used, with modification where necessary because of the smaller body size and variations in cranial anatomy of prepubertal mice. Except for aspirating the pituitary, all steps in the surgery for hypophysectomy were carried out on the sham-operated animals. Mice were given a solution of $5 \%$ glucose in water and maintained in cages with filter tops for $2,7,12$ or 17 weeks after surgery and then 
killed to recover oocytes. Before killing, the completeness of hypophysectomy was assessed according to the following criteria: small body size in comparison to control and sham-operated mice, presence of a closed vagina, absence of pituitary fragments in the sella turcica on examination with a binocular magnifier $(\times 2 \cdot 3)$, absence of uterine distension, presence of small ovaries free of corpora lutea when examined with a dissecting microscope. Hypophysectomized mice which did not meet all 6 requirements were not used as oocyte donors.

\section{Culture procedures}

Ovaries of 2-4 animals in a treatment group were pooled in an embryological watch glass containing $2.5 \mathrm{ml}$ culture medium under $2.0 \mathrm{ml}$ paraffin oil (Fisher, light-weight). The medium used was the standard medium for mouse ovum culture described by Biggers, Whitten \& Whittingham (1971) except that the bovine serum albumin (BSA) content was $4 \mathrm{mg} / \mathrm{ml}$ and the sodium pyruvate was $0.055 \mathrm{mg} / \mathrm{ml}$. Oocytes were obtained by puncturing the largest visible follicles with a 30-gauge needle. Those free of adhering cumulus cells were collected in a finelydrawn Pasteur pipette and washed once. Groups of 25 oocytes were placed in microdrops (50$100 \mu \mathrm{l})$ of medium under oil in $60 \times 15 \mathrm{~mm}$ plastic tissue culture dishes (Corning Glass Works) and maintained for $16-20 \mathrm{~h}$ at $37^{\circ} \mathrm{C}$ in an atmosphere of $5 \% \mathrm{CO}_{2}$ in air and $100 \%$ humidity (Brinster, 1963). At the end of the culture period, the stage of oocyte maturation was determined with the aid of a dissecting microscope. Oocytes were classified as mature, i.e. polar body (pb) extruded, meiotically inactive, i.e. germinal vesicle (gv) retained, or as having resumed but not completed the first meiotic division, i.e. germinal vesicle breakdown (gvbd). Cultured oocytes were scored as degenerate if they showed cytolysis, fragmentation, necrosis, vacuolization, or loss of spherical shape. Some of the oocytes in each category were fixed, stained with Giemsa (Rafferty, 1970) and examined by conventional light microscopy to confirm the diagnosis of stage of maturation. In one experiment (replicate 6) the diameters of oocytes from mice hypophysectomized for 2, 7 and 12 weeks were measured with an ocular micrometer.

\section{Histological procedures}

Ovaries of animals in all three treatment groups killed at various intervals after hypophysectomy were fixed in Bouin's fluid, sectioned at $8 \mu \mathrm{M}$ and stained with haematoxylin and eosin. Sectioned ovaries were examined for a qualitative assessment of the prominent histological features.

\section{Hormone replacement}

Mice were hypophysectomized and maintained as previously described for 4 weeks. Injection of replacement hormones or vehicles was then started. Three sets of experiments were carried out (Table 3), each with its own hypophysectomized and intact control groups. Statistical comparisons (see below) were made within each set of experiments but not between sets. There was a total of 8 different treatment groups in the 3 sets of experiments. (1) PMSG (Sigma Chemical Co.), 0.04 i.u./week in $0.4 \mathrm{ml} 0.9 \%(\mathrm{w} / \mathrm{v}) \mathrm{NaCl}$, was given as 3 intraperitoneal (i.p.) injections/week for 4 weeks. (2) Oestradiol-17ß (Sigma), $0.04 \mu \mathrm{g} /$ week in $0.2 \mathrm{ml}$ sesame oil, was given as 3 subcutaneous (s.c.) injections/week for 4 weeks. (3) PMSG + oestradiol-17 $\beta$ were given as a combination of the doses and injection schedules used in (1) and (2) above. (4) hCG (Sigma), 0.7 i.u./week in $0.4 \mathrm{ml} 0.9 \% \mathrm{NaCl}$, was given as 3 i.p. injections/week for 6 weeks. (5) Progesterone (Sigma), $0.4 \mathrm{mg} /$ week in $0.2 \mathrm{ml}$ sesame oil, was given as 3 s.c. injections/week for 6 weeks. (6) $0.9 \%(w / v) ~ N a C l$ was given as $0.4 \mathrm{ml} /$ week in 3 i.p. injections/week for 3 weeks. (7) Sesame oil, $0.2 \mathrm{ml} /$ week, was given as 3 i.p. injections/week for 3 weeks. (8) $0.9 \% \mathrm{NaCl}+$ sesame oil were given as a combination of the doses and injection schedules in (7) and (8) above. 
Table 1. Effect of hypophysectomy (hypox.) on mouse oocyte maturation in vitro

\begin{tabular}{|c|c|c|c|c|c|c|c|c|}
\hline \multirow[b]{2}{*}{$\begin{array}{l}\text { Time after } \\
\text { hypophy- } \\
\text { sectomy } \\
\text { (weeks) }\end{array}$} & \multirow[b]{2}{*}{ Treatment } & \multirow[b]{2}{*}{$\begin{array}{l}\text { No. of } \\
\text { experi- } \\
\text { ments }\end{array}$} & \multirow[b]{2}{*}{$\begin{array}{l}\text { No. of } \\
\text { ovaries }\end{array}$} & \multicolumn{5}{|c|}{ Oocytes } \\
\hline & & & & $\begin{array}{c}\text { No. } \\
\text { cultured }\end{array}$ & $\begin{array}{c}\text { No. not } \\
\text { degenerating } \\
\text { after } \\
16-20 \mathrm{~h} \\
(\%)^{*}\end{array}$ & $\begin{array}{l}\text { No. with } \\
\text { pb }(\%) \dagger\end{array}$ & $\begin{array}{l}\text { No. with } \\
\text { gvbd } \\
\text { (\%)† }\end{array}$ & $\begin{array}{l}\text { No. with } \\
\text { gv(\%) } \dagger\end{array}$ \\
\hline \multirow[t]{3}{*}{2} & Control & 6 & 64 & 408 & $336(82)$ & $272(81)$ & $58(17)$ & $6(2)$ \\
\hline & Sham-operated & 5 & 52 & 363 & $305(84)$ & $248(81)$ & 57 (19) & $0(0)$ \\
\hline & Hypox. & 6 & 70 & 386 & $315(82)$ & $247(78)$ & $64(20)$ & $4(1)$ \\
\hline \multirow[t]{3}{*}{7} & Control & 6 & 82 & 718 & $655(91)$ & $573(88)$ & $69(11)$ & $13(3)$ \\
\hline & Sham-operated & 5 & 76 & 577 & $514(89)$ & $460(90)$ & $43(8)$ & $11(2)$ \\
\hline & Hypox. & 6 & 88 & 535 & $408(76) \ddagger$ & $278(68) \ddagger$ & $102(25) \ddagger$ & $28(7) \ddagger$ \\
\hline \multirow[t]{3}{*}{12} & Control & 6 & 66 & 457 & $423(93)$ & $391(92)$ & $21(5)$ & $11(3)$ \\
\hline & Sham-operated & 5 & 60 & 410 & $359(88) \S$ & $329(92)$ & $27(7)$ & $3(1)$ \\
\hline & Hypox. & 6 & 69 & 346 & $277(80) \neq$ & $194(70) \ddagger$ & $69(25) \ddagger$ & $14(5) \ddagger$ \\
\hline \multirow[t]{3}{*}{17} & Control & 5 & 70 & 418 & $388(93)$ & $347(89)$ & $34(9)$ & $7(2)$ \\
\hline & Sham-operated & 5 & 68 & 387 & $360(93)$ & $338(94)$ & $20(6)$ & $2(<1)$ \\
\hline & Hypox. & 5 & 72 & 290 & $218(75) \ddagger$ & $148(68) \ddagger$ & $58(27) \ddagger$ & $12(5) \ddagger$ \\
\hline
\end{tabular}

$\mathrm{pb}$, Polar body; gv, germinal vesicle; gvbd, germinal vesicle breakdown.

* Of oocytes cultured.

$\dagger$ Of oocytes which did not degenerate.

¥ Significantly different from values for control and sham-operated groups, $P<0.02$.

$\S$ Significantly different from control group, $P<0.05$.

\section{Statistical analysis}

The results of replicate experiments were pooled as inspection indicated that they were similar. For the various categories of oocytes in each set of pooled data overall $\chi^{2}$ values were calculated by $2 \times 3$ contingency tables, as indicated by Maxwell (1961), and partitioned according to Maxwell (1961) or by Kimball's formulae (Everitt, 1977). The significance of differences between mean oocyte diameters of the three treatment groups within each time interval was determined by Student's $t$ test.

\section{Results}

\section{Oocyte maturation}

Table 1 shows that, at 2 weeks after surgery, there was no effect of hypophysectomy on mouse oocyte maturation or degeneration in vitro and no difference between sham-operated and control animals. However, by 7 weeks significantly fewer oocytes from hypophysectomized than from control or sham-operated animals extruded polar bodies. Of those which did not complete maturation, the majority resumed meiosis. There were also significantly more oocytes from hypophysectomized mice in the meiotically inactive (gv) group. In addition, significantly greater numbers of oocytes from hypophysectomized mice degenerated during the culture period. Similar results were obtained at 12 and 17 weeks after hypophysectomy.

Table 2 shows that there were no significant differences in diameter of cultured oocytes between control and hypophysectomized mice at 2,7 and 12 weeks after surgery.

Table 3 shows that the reduction in maturation by hypophysectomy could be partly overcome by the administration of PMSG, oestradiol-17 $\beta$ or PMSG + oestradiol. However, maturation was not returned to intact control levels by these treatments and there was no synergistic effect when PMSG was injected in conjunction with oestradiol. Since there were no significant differences in the numbers of oocytes resuming meiosis (at the gvbd stage) between 
Table 2. Effect of hypophysectomy (hypox.) on oocyte size (mean \pm s.e.m.)

\begin{tabular}{clcc}
\hline \multirow{2}{*}{$\begin{array}{c}\text { Time after } \\
\text { hypophysectomy } \\
\text { (weeks) }\end{array}$} & Treatment & \begin{tabular}{c} 
Oocytes \\
\cline { 3 - 4 } measured
\end{tabular} & $\begin{array}{c}\text { Diameter } \\
(\mu \mathrm{m})\end{array}$ \\
\hline 2 & Control & 45 & $72.6 \pm 0.74$ \\
& Hypox. & 82 & $71.2 \pm 0.46$ \\
7 & Control & 63 & $73.6 \pm 0.73$ \\
& Hypox. & 67 & $71.7 \pm 0.69$ \\
12 & Control & 31 & $75.6 \pm 1.01$ \\
& Hypox. & 26 & $72.8 \pm 1.21$ \\
\hline
\end{tabular}

hypophysectomized controls and PMSG- or oestradiol- (or both) treated mice, and fewer oocytes from hormone-treated animals retained a gv, these hormones appear to have stimulated both the resumption and completion of the first meiotic division. Neither hCG nor progesterone raised maturation rates over those obtained for hypophysectomized controls. None of the vehicles used for hormone administration influenced maturation rates.

\section{Ovarian morphology}

In the present experiments, ovaries were not serially sectioned and therefore the numbers of atretic cells in each follicle could not be accurately determined. Nevertheless, some general observations concerning the effect of the various treatments on ovarian morphology could be made. At all intervals after hypophysectomy ovaries were reduced in size from control or shamoperated mice since there were no corpora lutea or large antral follicles present. In the cortical regions the most prominent structures were large multilaminar or very early antral follicles with

Table 3. Effect of hypophysectomy (hypox.) and hormone replacement on mouse oocyte maturation in vitro

\begin{tabular}{|c|c|c|c|c|c|c|c|}
\hline \multirow[b]{2}{*}{ Treatment } & \multirow[b]{2}{*}{$\begin{array}{l}\text { No. of } \\
\text { experiments }\end{array}$} & \multirow[b]{2}{*}{$\begin{array}{l}\text { No. of } \\
\text { ovaries }\end{array}$} & \multicolumn{5}{|c|}{ Oocytes } \\
\hline & & & $\begin{array}{c}\text { No. } \\
\text { cultured }\end{array}$ & $\begin{array}{c}\text { No. not } \\
\text { degenerating } \\
\text { after } \\
16-20 \mathrm{~h} \\
(\%)^{*}\end{array}$ & $\begin{array}{l}\text { No. with } \\
\mathrm{pb}(\%) \dagger\end{array}$ & $\begin{array}{c}\text { No. with } \\
\text { gvbd } \\
(\%) \dagger\end{array}$ & $\begin{array}{r}\text { No. with } \\
\text { gv }(\%) \dagger\end{array}$ \\
\hline Hypox. + saline & 2 & 20 & 60 & $46(77)$ & $28(61)$ & $17(37)$ & $1(2)$ \\
\hline Hypox. + oil & 2 & 20 & 86 & $60(70)$ & $42(70)$ & $17(28)$ & $1(2)$ \\
\hline Hypox. + saline + oil & 2 & 16 & 86 & $52(61)$ & $31(60)$ & $18(35)$ & $3(6)$ \\
\hline Hypox. control & 2 & 20 & 77 & $60(78)$ & $36(60)$ & $19(32)$ & $5(8)$ \\
\hline Intact control & 2 & 12 & 75 & $68(91) \ddagger$ & $59(87) \ddagger$ & $8(12) \ddagger$ & $1(1)$ \\
\hline Hypox. + hCG & 2 & 14 & 47 & $37(79)$ & $21(57)$ & $16(43)$ & - \\
\hline Hypox. + progesterone & 2 & 12 & 64 & $42(66)$ & $17(40)$ & $25(60)$ & - \\
\hline Hypox. control & 2 & 12 & 71 & $65(92) \ddagger$ & $32(49)$ & $33(51)$ & - \\
\hline Intact control & 2 & 16 & 77 & $72(94)+$ & $67(93) \ddagger$ & $5(7) \ddagger$ & - \\
\hline Hypox. + PMSG & 2 & 22 & 136 & $112(82)$ & $81(72)$ & $29(26)$ & $2(2)$ \\
\hline Hypox. + oestradiol & 2 & 22 & 68 & $42(62) \ddagger$ & $30(71)$ & $11(26)$ & $1(2)$ \\
\hline Hypox. + PMSG + oestradiol & 2 & 16 & 41 & $31(76)$ & $23(74)$ & $8(26)$ & - \\
\hline Hypox. control & 2 & 24 & 87 & $65(75)$ & $36(55) \ddagger$ & $20(31)$ & $9(14) \ddagger$ \\
\hline Intact control & 2 & 22 & 173 & $140(81)$ & $129(92) \ddagger$ & $8(16) \ddagger$ & $3(2)$ \\
\hline
\end{tabular}

$\mathrm{pb}$, Polar body; gv, germinal vesicle; gvbd, germinal vesicle breakdown.

* Of oocytes cultured.

$\dagger$ Of oocytes which did not degenerate.

$\ddagger$ Significantly different from the values for the other groups, at least at $P<0.02$. 
several or many layers of granulosa cells associated with an undeveloped thecal layer. The central portions of ovaries from hypophysectomized mice were occupied by stroma containing hyalinized oocytes. The most prominent structures in ovaries from control and sham-operated mice were corpora lutea and large antral follicles. There did not appear to be any differences between control and sham-operated mice of the same age. The numbers of multilaminar follicles that were growing and/or undergoing atresia were not noticeably different at any of the intervals after hypophysectomy. In control ovaries and at all intervals after hypophysectomy the atresia in most follicles was not advanced according to the classification of Hay, Cran \& Moor (1976). Multilaminar follicles with proliferating granulosa cells as well as some atretic cells were often seen. In all ovaries from control mice atretic follicles at the large multilaminar or early antral stage were also seen, even though these stages represented a smaller proportion of the total population of ovarian structures in control and sham-operated than in hypophysectomized mice. Administration of PMSG, oestradiol or PMSG + oestradiol did not change the general appearance of the sections in comparison to ovaries from non-hormone treated mice hypophysectomized for the same length of time.

\section{Discussion}

The data presented indicate that by 7 weeks (but not at 2 weeks) after hypophysectomy, mouse oocytes obtained from the largest follicles have a reduced potential for maturation in vitro in spite of the fact that there are no differences in oocyte diameter between control and hypophysectomized mice at any interval following pituitary removal. In most mammals, oocytes have attained their maximum diameter by the time follicular development has reached the pre- or early-antral stage (Brambell, 1956; Mandl \& Zuckerman, 1952; Moore \& Lintern-Moore, 1974). Fully-grown oocytes mature spontaneously in vitro with a high frequency whereas oocytes which have not reached maximum diameter do not resume meiosis or proceed only to metaphase I (Iwamatsu \& Yanagimachi, 1975; Sorensen \& Wassarman, 1976). The diameters of the oocytes measured in the present experiments ranged between 71 and $75 \mu \mathrm{m}$, sufficient for maturation at a frequency of $90 \%$ if obtained from a normal mouse (Sorensen \& Wassarman, 1976). Therefore the decreased potential for spontaneous maturation must result from factors other than the failure of oocytes to reach a size adequate for spontaneous maturation in the absence of gonadotrophins.

The present results do not appear to be attributable to differences in follicular atresia at any stage after hypophysectomy. Ovaries were not serially sectioned but observation of the sectioned material did not indicate obvious differences in the numbers of growing and atretic follicles, or in the degree of atresia in multilaminar follicles at any of the intervals after hypophysectomy. Even if follicular degeneration had been different in the different treatment groups, atresia is not a good criterion for identifying follicles with reduced developmental potential. Half of the atretic follicles isolated from sheep ovaries yielded oocytes which were fertilizable and developed to blastocysts if these follicles were cultured in the presence of oestrogen during gonadotrophin induction of oocyte maturation (Moor \& Trounson, 1977). Furthermore, we have observed that some human oocytes which appear badly degenerated on recovery from dissected follicles can develop into ova with a normal metaphase II appearance in culture (K. P. McNatty \& D. M. Smith, unpublished results).

The morphological features of the ovaries of the hypophysectomized mice in the present study closely resemble those described by previous workers (Smith, 1930; Dempsey, 1937; deWit, 1953; Perry \& Rowlands, 1963; Mauleon, 1969; Merk, Botticelli \& Albright, 1972). The multilaminar follicles appear to be the product of new follicular growth in spite of the absence of gonadotrophins (Nakano, Mizuno, Katayama \& Tojo, 1975) as well as the result of a decreased rate of atresia (Jones \& Krohn, 1961). Whether this preantral granulosa development is physio- 
logically normal is not known although ovaries from mice hypophysectomized for at least 300 days were able to develop antra, ovulate and support pregnancy when orthotopically grafted into females with normal cyclic pituitary function (Jones \& Krohn, 1961).

In young animals there is conflicting evidence regarding the necessity of gonadotrophins for the early stages of follicular growth (Price \& Ortiz, 1944; Ben-Or, 1963; Eshkol \& Lunenfeld, 1971/72; Baker \& Neal, 1973; Peters, Byskov, Lintern-Moore, Faber \& Anderson, 1973; Challoner, 1975; Purandare, Munshi \& Rao, 1976; Lintern-Moore, 1977). Regardless of the necessity of gonadotrophins to initiate follicular growth in young animals, there is considerable evidence to suggest that either gonadotrophins or oestrogen must be present to ensure the normal morphological appearance of the growing granulosa cells. In juvenile mice, for example, administration of antisera to gonadotrophins interferes with follicular vascularization, produces morphological changes in theca and granulosa and alters the relationships between follicle cells in growing follicles, all of which can be corrected by administration of gonadotrophins (Eshkol, Lunenfeld \& Peters, 1970; Eshkol \& Lunenfeld, 1971/72; Hardy, Danon, Eshkol \& Lunenfeld, 1974). In hypophysectomized rats, the incidence of granulosa cell nexuses is reduced and can be increased by oestrogen administration (Merk et al., 1972). In the present experiments, oestrogen, PMSG or the two together, partly restored the potential for oocytes to mature spontaneously. This may have been due to fine structural alterations in the intercellular junctions in the preantral follicles since administration of oestrogen, PMSG, or both, 4 weeks after hypophysectomy did not appear, at the light microscopic level, to produce the follicular growth and development seen by other authors (Pencharz, 1940; Williams, 1944; deWit, 1953; Goldenberg, Vaitukaitis \& Ross, 1972; Harman, Louvet \& Ross, 1975; Nakano et al., 1977) when oestrogens were administered shortly after hypophysectomy. In the present experiments, the doses of oestradiol and PMSG administered were low and it is not known whether the full potential for spontaneous oocyte maturation would have been restored if enough oestrogen had been given to stimulate granulosa cell proliferation or enough PMSG to cause antrum formation (see Richards, 1978, for a review). Since oestradiol, PMSG and PMSG + oestradiol but not progesterone or hCG, partly restored the potential for spontaneous maturation, it can be suggested that the presence of oestrogen in the follicular environment is important for fully grown oocytes to be able to mature spontaneously in vitro. In the present experiments, however, we have not examined any effect that pituitary hormones other than gonadotrophins might have had in restoring maturation potential.

The suggestion that oestrogens in the environment of the oocyte might be important for development of full maturation potential is in contrast to the hypothesis of Erickson \& Sorensen (1974) and Erickson \& Ryan (1976) who considered that the capacity of granulosa cells to secrete progesterone was critical for development of full oocyte maturation potential. The involvement of oestrogen in the competence of fully grown oocytes to mature has been suggested previously. Hunter et al. (1976) found that ovulation could be induced in non-oestrous pigs by injection of hCG on Day 17 of the cycle but that oocytes did not resume meiosis unless ovulated by an oestrous female. Smith et al. (1978) showed that maturation in vitro was greatest when oocytes were obtained from monkeys which showed evidence of oestrogen secretion (reddening of the sex skin and/or oedema of the perineal region). Moor (1978) has reported that inclusion of oestradiol in the culture medium increased the number of sheep intrafollicular oocytes developing to metaphase II after gonadotrophin stimulation compared with the maturation frequency obtained with FSH or LH alone.

How an oestrogen-dominated follicular environment might affect nuclear maturation is not known but some insight may be gained from the work of Lintern-Moore, Moore \& Pantelouris (1976) who found that athymic "nude" mice have ovarian follicles with a contracted appearance closely resembling those of normal mice treated with anti-gonadotrophin (Hardy et al., 1974) and while oocyte growth appeared normal, oocyte nucleoli were reduced in size. Follicular growth was restored by PMSG injection. PMSG also increased oocyte nucleolar size and it was 
suggested that it could affect oogenesis at the molecular level by stimulating nucleolar RNA synthesis (Lintern-Moore et al., 1976). It is also possible that PMSG stimulated follicle cells to secrete oestrogen (see Richards, 1978) which in turn was responsible for restoring normal granulosa cell connections with each other and with the oocyte (Merk et al., 1972). It is possible that the communication between granulosa cells and between the granulosa and oocyte via the desmosomes and gap junctions present in mouse follicles with two or more layers of follicle cells (Anderson, 1971) is necessary before fully grown oocytes can resume and/or complete nuclear maturation before ovulation.

We are unable to agree with the conclusion of Eppig (1977) and Thibault (1977) that hormones are not involved in mammalian oocyte nuclear maturation. The results of Eppig (1977) do, in fact, support the idea that fully grown oocytes which have developed in vivo mature spontaneously in significantly greater numbers than do fully grown oocytes that developed in cultured follicles in medium devoid of gonadotrophins or steroids $\left(\chi_{1}^{2}=212.5\right.$ for polar body formation and 70.1 for resumption of meiosis for the data in Table 1 presented by Eppig, 1977). We suggest that the follicular endocrine environment before the ovulatory LH surge may be important in regulating the potential of the fully grown oocyte for nuclear maturation, just as the follicular environment after the LH surge is important in stimulating the cytoplasmic and membrane maturation necessary for fertilization and post-fertilization development (reviewed by Thibault, 1977; see also Trounson, Willadsen \& Rowson, 1977; Warnes, Moor \& Johnson, 1977).

We thank Professor J. D. Biggers for assistance with statistical analyses. Support was obtained from NICHD Grant No. HD-06916, NIH Center Grant No. HD-06645 and Rockefeller Foundation Grants No. RF 65040 and RF 77045.

\section{References}

Anderson, E. (1971) Intercellular junctions in the differentiating Graafian follicle of the mouse. Anat. Rec. 169, 473, Abstr.

Baker, T.G. \& Neal, P. (1973) Initiation and control of meiosis and follicular growth in ovaries of the mouse. Annls Biol. anim. Biochim. Biophys. 13, 137-144.

Ben-Or, S. (1963) Morphological and functional development of the ovary of the mouse. I. Morphology and histochemistry of the developing ovary in normal conditions and after FSH treatment. J. Embryol. exp. Morph. 11, 1-11.

Biggers, J.D., Whitten, W.K. \& Whittingham, D.G. (1971) The culture of mouse embryos in vitro. In Methods in Mammalian Embryology, pp. 86-116. Ed. J. C. Daniel, Jr. W. H. Freeman and Co., San Francisco.

Brambell, F.W.R. (1956) Ovarian changes. In Marshall's Physiology of Reproduction, Vol. I. pp. 455-457. Ed. A. S. Parkes. Longmans Green, London.

Brinster, R.L. (1963) A method for in vitro cultivation of mouse ova from two-cell to blastocyst. Expl Cell Res. 32, 205-208.

Challoner, S. (1975) Studies of oogenesis and follicular development in the golden hamster. 3. The initiation of follicular growth in vitro. J. Anat. 119, 157-162.

Dempsey, E.W. (1937) Follicular growth rate and ovulation after various experimental procedures in the guinea-pig. Am.J. Physiol. 120, 126-132.
deWit, J.E. (1953) The effect of oestradiol monobenzoate on follicles of various sizes in the ovary of the hypophysectomized rat. Acta endocr., Copenh. 12, 123-139.

Eppig, J.J. (1977) Mouse oocyte development in vitro with various culture systems. Devl Biol. 60, 371388.

Erickson, G.F. \& Ryan, K.J. (1976) Spontaneous maturation of oocytes isolated from ovaries of immature hypophysectomized rats. J. exp. Zool. 195, 153-158.

Erickson, G.F. \& Sorensen, R.A. (1974) In vitro maturation of mouse oocytes isolated from late, middle, and pre-antral Graafian follicies. J. exp. Zool. 190, 123-127.

Eshkol, A. \& Lunenfeld, B. (1971/72) Biological effects of antibodies to gonadotropins. Gynec. Invest. 2, 2356.

Eshkol, A., Lunenfeld, B. \& Peters, H. (1970) Ovarian development in infant mice. Dependence on gonadotropic hormones. In Gonadotropins and Ovarian Development, pp. 249-258. Eds W. R. Butt, A. C. Crooke \& M. Ryle. Livingstone, Edinburgh.

Everitt, B.S. (1977) The Analysis of Contingency Tables, pp. 41-44. Chapman \& Hall Ltd, London.

Goldenberg, R.L., Vaitukaitis, J.L. \& Ross, G.T. (1972) Estrogen and follicle stimulating hormone interactions on follicle growth in rats. Endocrinology 90, 1492-1498. 
Hardy, B., Danon, D. Eshkol, A. \& Lunenfeld, B. (1974) Ultrastructural changes in the ovaries of infant mice deprived of endogenous gonadotrophins and after substitution with FSH. J. Reprod. Fert. 36, 345-352.

Harman, S.M., Louvet, J.-P. \& Ross, G.T. (1975) Interaction of estrogen and gonadotropins on follicular atresia. Endocrinology 96, 1145-1152.

Hay, M.F., Cran, D.G. \& Moor, R.M. (1976) Structural changes occurring during atresia in sheep ovarian follicles. Cell Tiss. Res. 169, 515-529.

Hunter, R.H.F., Cook, B. \& Baker, T.G. (1976) Dissociation of response to injected gonadotropin between the Graafian follicle and oocyte in pigs. Nature, Lond. 260, 156-158.

Iwamatsu, T. \& Yanagimachi, R. (1975) Maturation in vitro of ovarian oocytes of prepubertal and adult hamsters. J. Reprod. Fert. 45, 83-90.

Jones, E.C. \& Krohn, P.L. (1961) The effect of hypophysectomy on age changes in the ovaries of mice. $J$. Endocr. 21, 497-509.

Lintern-Moore, S. (1977) Initiation of follicular growth in the infant mouse ovary by exogenous gonadotrophin. Biol. Reprod. 17, 635-639.

Lintern-Moore, S., Moore, G.P.M. \& Pantelouris, E.M. (1976) Abnormal nucleolar growth in the oocytes of athymic "nude" mice. Expl Cell Res. 97, 430-432.

Mand, A. \& Zuckerman, S. (1952) The growth of the oocyte and follicle in the adult rat. J. Endocr. 8, 126132.

Mauleon, P. (1969) Oogenesis and folliculogenesis. In Reproduction in Domestic Animals, pp. 187-215. Eds H. H. Cole \& P.T. Cupps. Academic Press, New York.

Maxwell, A.E. (1961) Analyzing Qualitative Data, pp. 11-62. Methuen, London.

Merk, F.B., Botticelli, C.R. \& Albright, J.T. (1972) An intercellular response to estrogen by granulosa cells in the rat ovary; an electron microscope study. Endocrinology 90, 992-1007.

Moor, R.M. (1978) Role of steroids in the maturation of ovine oocytes. Annls Biol. anim. Biochim. Biophys. 18, 477-482.

Moor, R.M. \& Trounson, A.O. (1977) Hormonal and follicular factors affecting maturation of sheep oocytes in vitro and their subsequent developmental capacity. J. Reprod. Fert. 49, 101-109.

Moore, G.P.M. \& Lintern-Moore, S. (1974) A correlation between growth and RNA synthesis in the mouse oocyte. J. Reprod. Fert. 39, 163-166.

Nakano, R., Mizuno, T., Katayama, K. \& Tojo, S. (1975) Growth of ovarian follicles in rats in the absence of gonadotrophins. J. Reprod. Fert. 45, 545546.
Nakano, R., Mizuno, T., Katayama, K. \& Tojo, S. (1977) Effect of follicle stimulating hormone (FSH) and estrogen on follicle growth in rats. Arch. Gynäk. 222, 333-344.

Pencharz, R. I. (1940) Effect of estrogens and androgens alone and in combination with chorionic gonadotropin on the ovary of the hypophysectomized rat. Science, N.Y. 91, 554-555.

Perry, J.S. \& Rowlands, I.W. (1963) Hypophysectomy of the immature guinea-pig and the ovarian response to gonadotrophins. J. Reprod. Fert. 6, 393-404.

Peters, H., Byskov, A.G., Lintern-Moore, S., Faber, M. \& Anderson, M. (1973) The effect of gonadotrophin on follicle growth initiation in the neonatal mouse ovary. J. Reprod. Fert. 35, 139-141.

Price, S. \& Ortiz, E. (1944) The relation of age to reactivity in the reproductive system of the rat. Endocrinology 34, 215-239.

Purandare, T.V., Munshi, S.R. \& Rao, S.S. (1976) Effect of antisera to gonadotropins on follicular development and fertility of mice. Biol. Reprod. 15, 311320 .

Rafferty, K.A., Jr (1970) Methods in Experimental Embryology of the Mouse, pp. 22-23. Johns Hopkins Press, Baltimore.

Richards, J.S. (1978) Hormone regulation by hormone receptors in ovarian tissues. In Ovarian Follicular Development and Function. Eds. A. R. Midgley, Jr \& W. A. Sadler. Raven Press, New York.

Smith, D.M., Conaway, C.H. \& Kerber, W.T. (1978) Influences of season and age on maturation in vitro of rhesus monkey oocytes. J. Reprod. Fert. 54, 91-95.

Smith, P.E. (1930) Hypophysectomy and a replacement therapy in the rat. Am.J. Anat. 45, 205-273.

Sorensen, R.A. \& Wassarman, P.M. (1976) Relationship between growth and meiotic maturation of the mouse oocyte. Devl Biol. 50, 531-536.

Thibault, C. (1977) Are follicular maturation and oocyte maturation independent processes? J. Reprod. Fert. $51,1-15$.

Trounson., A.O., Willadsen, S.M. \& Rowson, L.E.A. (1977) Fertilization and developmental capacity of bovine follicular oocytes matured in vitro and in vivo and transferred to the oviducts of rabbits and cows. J. Reprod. Fert. 51, 321-327.

Warnes, G.M., Moor, R.M. \& Johnson, M.H. (1977) Changes in protein synthesis during maturation of sheep oocytes in vivo and in vitro. J. Reprod. Fert. 49, $331-335$.

Williams, P.C. (1944) Ovarian stimulation by oestrogens: effects in immature hypophysectomized rats. Proc. $R$. Soc, Lond. B 132, 189-199.

Zarrow, M.X., Yochim, J.M. \& McCarthy, J.L. (1964) Experimental Endocrinology A Sourcebook of Basic Techniques, pp. 308-310. Academic Press, New York. 